\title{
PENGARUH SISTEM PENGUPAHAN TERHADAP KINERJA PEGAWAI KERJA MUSIMAN DI PTPN X(PABRIK GULA CAMMING) KABUPATEN BONE
}

\author{
Andi Arwin Mustafa ${ }^{1}$, Muhlis Madani ${ }^{2}$,Nuryanti Mustari ${ }^{3}$ \\ 1) Jurusan Ilmu Administrasi Negara \\ 2) Jurusan Ilmu Administrasi Negara \\ 3) Jurusan Ilmu Administrasi Negara
}

\begin{abstract}
The aims of this research is to determine the wage level about wage system and the effect of the wage system towards the performance of seasonal employees in PTPN X (Sugar Factory of Camming Bone). The research applied descriptive qualitative type. The population of this study involves all the seasonal workers of the grinding section which consist of 65 employees as the samples. The results of this study indicate that the wage system reaches $79.2 \%$ or it is in good category andthe employees performance reaches $83 \%$ or is in very good category. Later, based on the results of the hypothesis test, itindicates that there is a significant influence between the wage system and the performance of seasonal employees in PTPN X (Sugar Factory of Camming Bone).
\end{abstract}

Keywords: wage system, employee performance

\begin{abstract}
ABSTRAK
Tujuan penelitian ini adalah untuk mengetahui tingkat pengupahan tentang sistem pengupahan, pengaruh sistem pengupahan terhadap kinerja pegawai kerja musiman di PTPN X (Pabrik Gula Camming Bone). Penelitian ini menggunakan deskriptif kuantitatif. Populasi dalam penelitian ini seluruh pekerja musiman bagian penggilingan dan sampel sebanyak 65 pegawai. Hasil penelitian ini menunjukan bahwa sistem pengupahan mencapai nilai $79,2 \%$ atau berada dalam kategori baik, kinerja pegawai mencapai nilai $83 \%$ atau berada dalam kategori sangat baik. Kemudian dari hasil uji hipotesis menunjukanadanya pengaruh signifikan antara sistem pengupahan terhadap kinerja pegawai kerja musiman di PTPN X (Pabrik Gula Camming Bone).
\end{abstract}

Kata kunci: sistem pengupahan, kinerja pegawai 


\section{PENDAHULUAN}

Perkembangan dunia usaha saat ini semakin bertambah pesat, sehingga perusahaan dalam menggelolah usaha diharapkan mampu menggunakan sumber daya manusia dengan baik dan benar. Sumber daya manusia merupakan bagian yang cukup penting dalam pencapaian tujuan organisasi baik itu perusahaan besar maupun kecil, suatu perusahaan memiliki peralatan yang modern dengan teknologi tinggi. Tujuan memahami dan mempelajari manajemen sumber daya manusia sebagai pengetahuan yang diperlukan untuk memiliki kemampuan analisa dalam menghadapi masalah-masalah manajemen khususnya dibidang organisasi. Kedudukan SDM khususnya tentang mutu, sumber daya manusia dalam suatu sistem yang lebih besar yaitu strategi organisasi.

Berbagai rangsangan faktor motivasi kerja dapat meningkatkan kinerja karyawan, pada umumnya manusia bekerja pada suatu perusahaan mempunyai tujuan untuk mendapatkan upah guna memenuhi kebutuhan hidupnya dengan terpenuhinya kebutuhan karyawan maka akan tercipta suasana kerja yang menyenangkan dilingkungan perusahaan. Mengingkat faktor tenaga kerja merupakan faktor yang terpenting dalam pelaksanaan proses produksi maka diperlukan tenaga kerja yang mempunyai keterampilan dan keahlian demi kelangsungan hidup perusahaan. Perusahaan PTPN X pabrik gula Camming Kabupaten Bone, memiliki sistem upah yang tidak adil bagi perkerja musiman karena sebelum penggilingan atasan menargetkan hasil giling 50 ton, penggilingan berlangsung dan pimpinan melihat targetnya akan dicapai jadi atasan menaikkan lagi targetnya 70 ton dan target itu akan dicapai maka atasan menaikkan lagi targetnya 85 ton, target tersebut tidak dicapai, atasan mengatakan merugi jadi upah pekerja musiman tidak dinaikkan karna perusahaan.

Berbagai rangsangan faktor motivasi kerja dapat meningkatkan kinerja karyawan, pada umumnya manusia bekerja pada suatu 
perusahaan mempunyai tujuan untuk mendapatkan upah guna memenuhi kebutuhan hidupnya dengan terpenuhinya kebutuhan karyawan maka akan tercipta suasana kerja yang menyenangkan dilingkungan perusahaan. Mengingat faktor tenaga kerja merupakan faktor yang terpenting dalam pelaksanaan proses produksi maka diperlukan tenga kerja yang mempunyai keterampilan dan keahlian demi kelangsungan hidup perusahaan. Agar tenaga kerja yang digunakan perusahaan dapat bekerja dengan baik, maka hendaknya pimpinan perusahaan harus memperhatikan segala kebutuhan yang berhubungan dengan karyawan.

Upah sangat berpengaruh terhadap kinerja karyawan. Seorang karyawan yang mempunyai upah tinggi atau sesuai dengan yang diharapkan, begitu pula lingkungan kerja yang menyenangkan maka akan tercapainya maksud dan tujuan perusahaan.

Perusahaan dapat berkembang merupakan keinginan setiap individu yang berada dalam perusahaan tersebut, sehingga diharapkan dengan perkembangan tersebut perusahaan mampu bersaing dalam mengikuti perkembangan zaman. Karena itu, tujuan yang diharapkan oleh perusahaan dapat tercapai dengan baik. Kemajuan perusahaan dipengaruhi oleh faktor-faktor lingkungan yang bersifat intenal dan eksternal. Sejauh mana tujuan perusahaan telah tercapai dapat dilihat dari seberapa besar perusahaan memenuhi tuntutan lingkungannya (Rivai, 2005). Indikator upah menurut (As`ad, 1987) antara lain :1) Sistem pengupahan, 2) Sistem upah menurut produksi, 3) Sistem upah menurut senioritas, 4) Sistem upah menurut kebutuhan. Sedangkan indikator upah menurut Simamora (2004) diantaranya : 1) Upah dan gaji, 2) Insentif, 3) Tunjangan, 4) Fasilitas. Menurut (Hasibun, 2002: 59) unsur-unsur penilaian kinerja adalah sebagai berikut: 1) Prestasi, penilaian hasil kerja baik kualitas maupun kuantitas yang dapat di hasilkan karyawan. 2) Kedisiplinan, penilaian disiplin dalam mematuhi peraturanperaturan yang ada dan melakukan 
pekerjaan sesuai dengan intruksi yang diberikan kepadanya. 3) Kreatifitas, penilaian kemampuan karyawan dalam mengembangkan kreatifitas untuk menyelesaikan pekerjaannya sehingga dapat bekerja lebih berdaya guna dan berhasil guna. 4) Bekerja sama, penilaian kesediaan karyawan berpartipasi dan bekerja sama dengan karyawan lain secara vertikal atau horizontal didalam maupun diluar sehingga hasil pekerjaannya lebih baik.

5) Kecakapan, penilaian dalam menyatukan dan melaraskan bermacam-macam elemen yang terlibat dalam menyusun kebijaksanaan dan dalam situasi manajemen. 6) Tanggung jawab, penilaian kesediaan karyawan dalam mempertanggung jawabkan kebijaksanaannya, pekerjaan dan hasil kerjanya, sarana dan prasarana yang digunakan, serta perilaku pekerjaannya.

\section{Kondisi lingkungan kerja} dikatakan baik atau sesuai apabila manusia dapat melaksanakan kegiatan secara optimal, sehat, aman, dan nyaman. Kesesuaian lingkungan kerja dapat dilihat akibatnya dalam jangka waktu yang lama lebih jauh lagi lingkungan-lingkungan kerja yang kurang baik dapat menuntut tenaga kerja dan waktu yang lebih banyak dan tidak mendukung diperolehnya rancangan sistem kerja yang efisien (Sedarmayanti, 2001). Setiap karyawan dalam melaksanakan kewajiban atau tugas merasa bahwa hasil kerja mereka tidak terlepas dari penilaian atasan baik secara langsung maupun tidak langsung. Penilaian kinerja digunakan untuk mengetahui kinerja seorang karyawan. Menurut Mangkunegara (2017: 67) "kinerja adalah hasil kerja yang dihasilkan oleh seorang karyawan untuk mencapai tujuan yang diharapkan. Menurut (Rivai, 2005) manfaat penilaian kinerja adalah 1) Manfaat bagi karyawan, 2) Manfaat bagi penilai, 3) Manfaat bagi perusahaan.

Menurut Abdullah (2014), indikator kinerja adalah ukuran kuantitatif atau kualitatif yang menggambarkan tingkat pencapaian suatu sasaran atau tujuan yang telah ditetapkan. Indikator kinerja digunakan untuk meyakinkan 
bahwa kinerja organisasi/unit kerja yang bersangkutan menunjukkan peningkatan kemampuan dalam rangka menuju tujuan dan sasaran yang telah ditetapkan. Secara umum, indikator kinerja memiliki fungsi sebagai berikut. Memperjelas tentang apa, berapa dan kapan kegiatan dilaksanakan menciptakan konsensus yang dibangun oleh berbagai pihak terkait untuk menghindari kesalahan interpretasi selama pelaksanaan kebijakan/program/kegiatan dan dalam menilai kinerjanya. Membangun dasar bagi pengukuran, analisis dan evaluasi kinerja organisasi/unit kerja.

Menurut Moeheriono (2014), mengemukakan empat kategori ukuran indikator kinerja, sebagai berikut: 1) Produktivitas, 2) Efektif, 3) Efesien, 4) Kualitas. Prawirosentono (2008: 27), berdasarkan pengertian kinerja di atas, maka kinerja individu berarti orang yang berperan dalam suatu organisasi yang memiliki sikap disiplin, inisiatif dan tanggung jawab masing-masing dalam rangka mencapai tujuan bersama oleh seseorang yang berada pada badan atau lembaga pemerintah yang menjalankan fungsi atau tugas pemerintahan menjadi lebih baik.

(2010: 198), Indikator kinerja
merupakan sesuatu yang akan dihitung dan diukur serta digunakan sebagai dasar untuk menilai atau melihat tingkat kinerja, baik dalam tahap perencanaan, pelaksanaan, maupun setelah kegiatan selesai. Indikator kinerja digunakan untuk meyakinkan bahwa kinerja organisasi/unit kerja yang bersangkutan menunjukkan peningkatan kemampuan dalam rangka menuju tujuan dan sasaran yang telah ditetapkan. Secara umum, indikator kinerja memiliki fungsi sebagai berikut. Memperjelas tentang apa, berapa dan kapan kegiatan dilaksanakan menciptakan konsensus yang dibangun oleh berbagai pihak terkait untuk menghindari kesalahan interpretasi selama pelaksanaan kebijakan/program/kegiatan dan dalam menilai kinerjanya. Membangun dasar bagi pengukuran, analisis dan evaluasi kinerja organisasi/unit kerja.

Kinerja individu dalam organisasi merupakan jawaban berhasil 
atau tidaknya tujuan organisasi yang telah ditetapkan, para aparatur sering tidak memperhatikan kecuali sudah amat buruk atau segala sesuatu yang tidak diinginkan terjadi, maka upaya yang harus dilakukan adalah menanamkan sikap Intropeksi diri.

Menurut Sugiyono (2012), Hipotesis merupakan jawaban sementara terhadap rumusan masalah penelitan, di mana rumusan masalah penelitian telah dinyatakan dalam bentuk kalimat pertanyaan. Dikatakan sementara, karena jawaban yang diberikan baru didasarkan pada teori yang relevan, belum didasarkan pada fakta-fakta empiris yang diperoleh melalui pengumpulan data. Jadi hipotesis juga dapat dinyatakan sebagai jawaban teoritis terhadap rumusan masalah penelitian, belum jawaban yang empirik.

\section{METODE PENELITIAN}

Adapun waktu yang dilakukan dalam meneliti adalah selama kurang lebih dua bulan yaitu kurang lebih dua bulan yaitu tanggal 25 februari-25 April 2017 di PTPN X (Pabrik Gula Camming Bone).
Jenis penelitian ini adalah penelitian kuantitatif, metode penelitian kuantitatif digunakan untuk pencarian data atau informasi dari realitas permasalah yang ada dengan mengacu pada pembuktian konsep atau teori yang digunakan. Selain itu penelitian ini bertujuan untuk mengetahui hubungan yang ada antara variabel-variabel penelitian. Penelitian tidak membuat perlakuan, karena peneliti dalam mengumpulkan data, yaitu berdasarkan dari sumber data, bukan pandangan peneliti.

Tipe penelitian ini adalah penelitian survey. Informasi diperoleh dengan mencari data-data yang berhubungan dengan masalah penelitian, maka dasar penelitian yang digunakan adalah survey, yaitu untuk mengetahui pengaruh sistem pengupahan terhadap kinerja pegawai keja musiman di PTPN X pabrik gula Camming Bone.

Populasi pada penelitian ini adalah seluruh pekerja musiman bagian penggilingan di PTPN $X$ (pabrik gula Camming Bone). Sample menurut Sugiyono (2012), sampel 
adalah bagian dari jumlah dan karakteristik yang dimiliki oleh populasi tersebut. Teknik penarikan sampel yang digunakan dalam penelitian ini adalah sampel jenuh. Penelitian ini yang merupakan sampel adalah pegawai kerja musiman di PTPN X (pabrik gula Camming Bone) yang berjumlah 65 orang (sampel/total).

\section{HASIL DAN PEMBAHASAN}

Berdasarkan dengan tujuan penelitian yang tercantum pada bab sebelumnya, yaitu untuk mengetahui bagaimana tingkat pengupahan tentang sistem pengupahan pegawai musiman di PTPN X (Pabrik Gula Camming
Bone), apakah sistem pengupahan berpengaruh terhadap kinerja pegawai kerja musiman di PTPN X (Pabrik Gula Camming Bone).

Berdasarkan penelitian yang dilakukan terhadap 65 pekerja musimandi PTPN X (Pabrik Gula Camming Bone), ditemukan kelompok usia responden antara 30-39 tahun ternyata lebih banyak jumlahnya dibandingkan dengan kelompok usia lainnya.

Berdasarkan hasil penelitian tentang sistem pengupahan di PTPN X (Pabrik Gula Camming Bone) maka dapat dirangkum dalam satu tabel, yaitu sebagai berikut:

Tabel 1.

Sistem Pengupahan

\begin{tabular}{|c|l|c|c|}
\hline NO & \multicolumn{1}{|c|}{ Indikator } & $\begin{array}{c}\text { Rata-rata } \\
\text { Skor }\end{array}$ & Kategori \\
\hline 1 & Upah dan gaji & $83,17 \%$ & Sangat Baik \\
\hline 2 & Intensif & $80,30 \%$ & Sangat Baik \\
\hline 3 & Tunjangan & $76,67 \%$ & Baik \\
\hline 4 & Fasilitas & $77,65 \%$ & Baik \\
\hline
\end{tabular}

Sumber : Hasil olahan kuesioner 
Untuk mengetahui sistem pengupahan di PTPN X (Pabrik Gula Camming Bone), berdasarkan indikator yang telah dikemukakan sebelumnya, maka dapat dijelaskan bahawa indikator pertama tentang upah dan gaji menjawab pertanyaan peneliti berada dalam kategori sangat baik, Hal tersebut terjadi karena dengan upah dan gaji pegawai mampu untuk menciptakan kerja yang baik. Kerja yang baik memberikan kepuasan kepada atasan dan masyarakat. Dalam hal ini pegawai di PTPN X pabrik gula Camming Bone yang mendapatkan upah dan gaji yang tinggi dapat memberikan kinerja yang baik terhadap perusahaan. Indikator kedua tentang intensif menjawab pertanyaan peneliti berada dalam kategori sangat baik, intensif memberikan tanggungjawab dan dorongan kepada pekerja musiman. Insentif menjamin bahwa pekerja musiman akan mengarahkan usahanya untuk mencapai tujuan perusahaan. Indikator ketiga tunjangan menjawab pertanyaan peneliti berada dalam kategori baik, pemberian tunjangan bagi karyawan dapat menunjang kesejahteraan karyawan yang juga akan menciptakan ketenangan, semangat kerja, dedikasi, disiplin dan sikap loyal terhadap perusahaan. Indikator keempat fasilitas menjawab pertanyaan peneliti berada dalam kategori baik, pemberian fasilitas suatu bentuk pelayanan perusahaan terhadap karyawan agar menunjang kinerja dalam memenuhi kebutuhan karyawan, sehingga dapat meningkatkan kinerja karyawan”.

Adanya fasilitas kerja yang disediakan oleh perusahaan sangat mendukung karyawan dalam bekerja. Fasilitas kerja tersebut sebagai alat atau sarana dan prasarana untuk membantu karyawan agar lebih mudah menyelesaikan pekerjaannya dan karyawan akan bekerja lebih produktif. Dengan adanya fasilitas kerja karyawan akan merasa nyaman dalam bekerja dan menimbulkan semangat kerja untuk mendapatkan hasil yang diharapkan oleh perusahaan. Fasilitas kerja dapat dilihat dari adanya fasilitas pendukung seperti : fasilitas ibadah, toile / WC dan lain-lain. 
Tabel 2.

Kinerja Pegawai

\begin{tabular}{|c|l|c|c|}
\hline NO & \multicolumn{1}{|c|}{ Indikator } & $\begin{array}{c}\text { Rata-rata } \\
\text { Skor }\end{array}$ & Kategori \\
\hline 1 & Produktivitas & $84,24 \%$ & SangatBaik \\
\hline 2 & Efektivitas & $81,41 \%$ & SangatBaik \\
\hline 3 & Efisiensi & $81,90 \%$ & SangatBaik \\
\hline 4 & Kualitas & $82,82 \%$ & Sangat Baik \\
\hline
\end{tabular}

Sumber : Hasil olahan kuesioner

Untuk mengetahui kinerja pegawaidi PTPN X (Pabrik Gula

Camming Bone), berdasarkan indikator yang telah dikemukakan sebelumnya, maka dapat dijelaskan bahawa indikator pertama tentang Produktivitas menjawab pertanyaan peneliti berada dalam kategori sangatbaik, Hal tersebut terjadi karena karyawan telah melaksanakan tugas kewajiban dan tanggung jawabnya maka selayaknyalah kepentingan pribadinya sebagai tenaga kerja dan secara manusiawi mendapat pelayanan yang baik dan lancar, kondisi ini memungkinkan timbulnya kepuasan kerja yang berpengaruh kepada dedikasi, loyalitas moral, dan semangat kerja yang tinggi akan membentuk disiplin kerja yang tinggi pula dan hal ini tercermin dalam kesediaan dan kesungguhan karyawan menunaikan pekerjaannya yang akan bermuara pada peningkatan produktivitas kerja. Indikator kedua tentang efektivitas menjawab pertanyaan peneliti berada dalam kategori sangat baik, Hal tersebut terjadi karena keberhasilan organisasi dalam mencapai tujuannya tidak dapat melepaskan diri dari perlunya pembagian kerja yang tepat supaya setiap pegawai bisa melaksanakan tugas-tugasnya secara efektif.

Pengukuran efektivitas kerja yang penulis lakukan didasarkan atas banyaknya tugas yang dipikul dan jumlah pegawai yang melaksanakan 
tugas tersebut, sehingga dari kedua hal tersebut dapat disusun sesuai dengan kebutuhan perusahaan/organisasi sehingga menghasilkan efektivitas kerja sebagaimana yang diharapkan oleh perusahaan. Indikator ketiga efisiensi menjawab pertanyaan peneliti berada dalam kategori sangat baik, Hal tersebut terjadi karena efisiensi dalam lingkungan kerja merupakan waktu yang dibutuhkan untuk menyelesaikan pekerjaan. Karyawan dan manajer yang efisien akan menyelesaikan pekerjaan secepat mungkin. Seperti yang dilakukan manajer pabri gula Camming Bone yang berkomunikasi secara lebih efektif.

$\begin{array}{rrr}\text { Karyawan } & \text { dan } & \text { manajer } \\ \text { menyelesaikan } & \text { target } & \text { dengan }\end{array}$
menggunakan waktu yang lebih cepat. Indikator keempat kualitas menjawab pertanyaan peneliti berada dalam kategori sangat baik, kualitas kerja didapatkan melalui persiapan yang lengkap terhadap semua komponen yang terkait dalam menghasilkan kualitas. Jadi, kesadaran manajemen untuk melengkapi sumber daya manusia dengan pengetahuan, data, informasi, cara kerja, teknologi, integritas, dan kepedulian kepada suasana hati mereka, akan menjadi kekuatan yang membuat kualitas kerja menjadi lebih unggul.

Pengujian hipotesis dilakukan untuk mengetahui sejauh mana hasil uji statistik menentukan diterima atau tidaknya hipotesis yang diajukan. Model yang digunakan dalam penelitian ini adalah Model Analisis Regresi Linear Sederhana. Model ini digunakan untuk menguji pengaruh sistem pengupahan (X) terhadap kinerja pegawai (Y).

Hasil perhitungan analisis regresi linier sederhana dengan menggunakan bantuan program SPSS versi 16 disajikan pada tabel berikut ; $\mathrm{Y}=20,772+0,091 \mathrm{X}$. Persamaan di atas menunjukkan bahwa nilai konstanta $=20,772$. Artinya bahwa dengan menganggap variabel independent constant, maka nilai sistem pengupahan sebesar 20,772satuan.

Bila terjadi penambahan nilai variabel promosi jabatan (X) sebesar 1 
satuan akan meningkatkan nilai kinerja asumsi variabel lain tetap.

pegawai sebesar 0,091 satuan dengan

Tabel 3.

Uji Validitas Variabel $\mathrm{X}$ (sistem pengupahan)

\begin{tabular}{|c|c|c|}
\hline Item Pernyataan & r Hitung & Keterangan \\
\hline 1 & 0,608 & Valid \\
\hline 2 & 0,591 & Valid \\
\hline 3 & 0,669 & Valid \\
\hline 4 & 0,554 & Valid \\
\hline
\end{tabular}

Sumber : Data kuesioner diolah

Tabel 4.

Uji Validitas Variabel Y ( kinerja pegawai)

\begin{tabular}{|c|c|c|}
\hline Item Pernyataan & r Hitung & Keterangan \\
\hline 1 & 0,603 & Valid \\
\hline 2 & 0,512 & Valid \\
\hline 3 & 0,729 & Valid \\
\hline 4 & 0,638 & Valid \\
\hline
\end{tabular}

Sumber : Data kuesioner diolah

Tabel 5.

Uji Realibilitas X dan Y

\begin{tabular}{|l|c|c|}
\hline \multicolumn{1}{|c|}{ Item Pernyataan } & Cronbach's Alpha & Keterangan \\
\hline sistem pengupahan & 0,737 & Valid \\
\hline Kinerja pegawai & 0,743 & Valid \\
\hline
\end{tabular}

Sumber : Data kuesioner diolah

Analisis model dan pengujian hipotesis yang diajukan. Model yang hipotesis dilakukan untuk mengetahui digunakan dalam penelitian ini adalah sejauh mana hasil uji statistik Model Analisis Regresi Linear menentukan diterima atau tidaknya Sederhana. Model ini digunakan untuk 
menguji pengaruh sistem pengupahan (X) terhadap kinerja pegawai (Y). Hasil perhitungan analisis regresi linear sederhana dengan menggunakan bantuan program SPSS versi 16 disajikan pada tabel berikut:

Tabel 6

\section{Coefficients $^{\mathbf{a}}$}

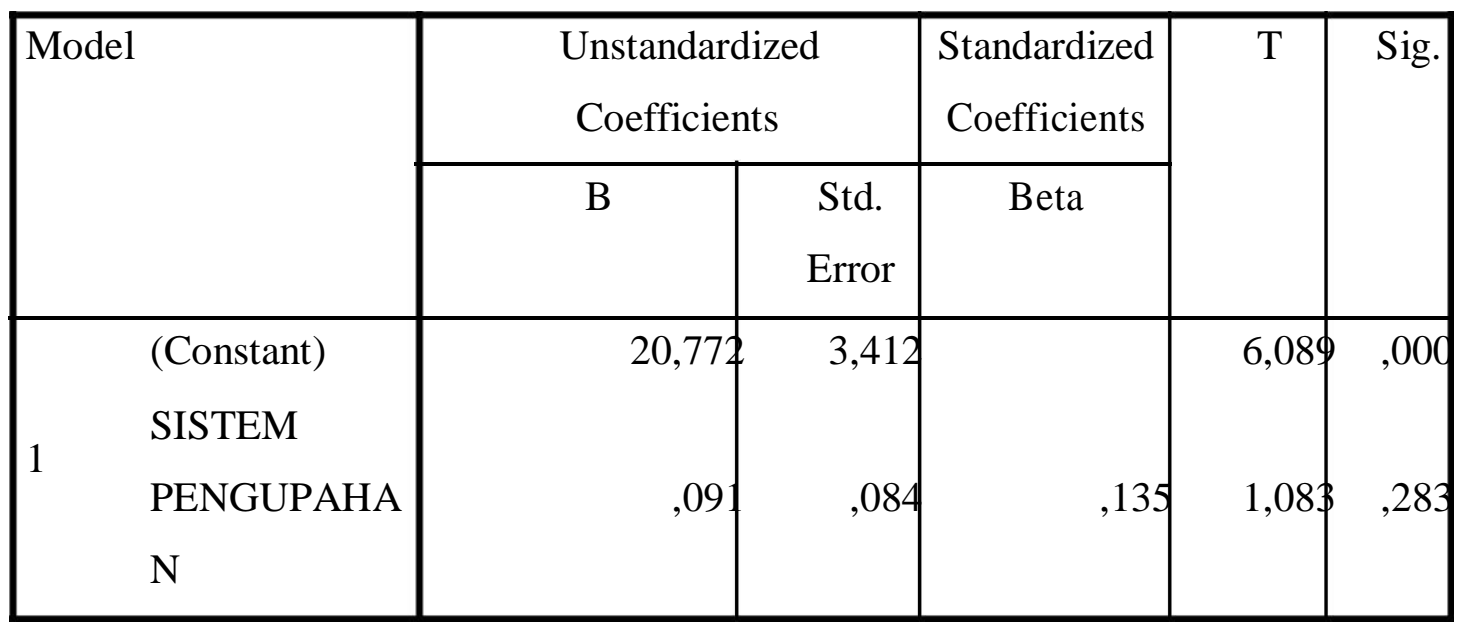

Sumber : Data kuesioner diolah

Hasil pengujian untuk variabel sistem pengupahan $(\mathrm{X})$ didapatkan $\mathrm{t}$ hitung sebesar 1,083 artinya lebih kecil dari t tabel = 1,669 (n-k dengan jumlah 65 sampel dan 2 jumlah variabel). Selain itu, dengan menggunakan nilai signifikansi yang didapatkan dari hasil pengujian yaitu 0,283 yang artinya lebih besar dari 0,05 sehingga $\mathrm{H}_{0}$ di tolak dan menerima $\mathrm{Ha}$ yaitu ada pengaruh sistem pengupahan (X) dengankinerja pegawai(Y).
Untuk menghitung apakah ada pengaruh signifikan antara variabel $X$ (independen) dan Y (dependen), maka menggunakan rumus regresi linear yaitu $\mathrm{Y}=20,772+$ 0,091X. Artinya, nilai a adalah konstanta sebesar 20,772, jika pengaruh sistem pengupahan $(\mathrm{X})$ nilainya 0 (nol), maka tingkat kinerja Pegawai (Y) nilainya positif sebesar0,091, nilai b adalah koefisien regresi sebesar 0,091, berarti jika sistem pengupahan (X) mengalami kenaikan 1 (satu), maka tingkat kinerja 
Pegawai mengalami peningkatan sebesar 0,091. Dari ketentuan tingkat signifikasi, yaitu: Ho $\mathrm{P}(\operatorname{sign}) \leq \alpha=$ Ho ditolak, sedangkan Ha diterima. Lihat tabel koefisien dihalaman sebelumnya bahwa sign 0,000 , itu berarti nilai $\mathrm{P}$ value : $0,05=0,000<0,05$. Dari perhitungan ini berarti Ho ditolak dan Ha diterima. Jadi, dapat disimpulkan bahwa terdapat pengaruh antara sistem pengupahan $(\mathrm{X})$ dengan kinerja Pegawai (Y) di di PTPN X (Pabrik Gula Camming Bone).

Untuk menghitung besarnya pengaruh antara pengaruh sistem pengupahan $(\mathrm{X})$ dengan kinerja Pegawai (Y), maka menggunakan rumus determinan ( $\mathrm{R}$ square) $\mathrm{Cd}=\mathrm{r}^{2}$ x $100 \%=0,135^{2} \times 100 \%=18 \%$. Artinya besarnya pengaruh Sistem Pengupahan (X) terhadap Kinerja Pegawai (Y) yaitu $18 \%$ dan sisanya $82 \%$ dipengaruhi oleh faktor lain yang tidak diteliti oleh peneliti. Maka hipotesis yang dinyatakan terdapat hubungan antara pengaruh sistem pengupahan $(\mathrm{X})$ dengan kinerja Pegawai (Y), atau tidak terdapat perbedaan antara yang diduga dengan data yang dikumpulkan.

Kemudian berdasarkan data diperoleh, skor ideal pada instrumen variabel X adalah 5 × $20 \times 65=6,500$. bila setiap butir mendapatkan skor terendah yaitu : $1 \times 20 \times 65=1,300$, ( 5 nilai tertinggi, 1 = nilai terendah, $20=$ jumlah item pernyataan yang valid, 65 $=$ jumlah responden). Skor penilaian adalah jumlah pengumpulan data variabel $\mathrm{X}$ 5149. Dengan demikian nilai pengaruh sistem pengupahan adalah $5,149: 6,500=$ 0,792 maka dalam persentase menjadi 79,2 persen.

Selanjutnya berdasarkan data diperoleh, skor ideal pada instrumen variabel Y adalah 5 × $20 \times 65=6,500$. bila setiap butir mendapatkan skor terendah yaitu : 1 × $20 \times 65=1,300$, ( 5 nilai tertinggi, $1=$ nilai terendah, 20 $=$ jumlah item pernyataan yang valid, $65=$ jumlah responden). Skor penilaian adalah jumlah pengumpulan data variabel $Y$ 5398. Dengan demikian nilai pengaruh Kinerja pegawai adalah $5,398: 6,500=0,83$ 
maka dalam persentase menjadi 83 persen.

\section{KESIMPULAN}

Berdasarkan hasil penelitian

yang dilakukan oleh penulis di PT. Perkebunan Nusantara X (Pabrik Gula Camming) Kabupaten Bone dengan judul "Pengaruh Sistem Pengupahan Terhadap Kinerja Pegawai Kerja Musiman di PT. Perkebunan Nusantara X (Pabrik Gula Camming) Kabupaten Bone", maka dengan ini penulis memberikan kesimpulan sebagai berikut: 1) Berdasarkan perhitungan dapat diketahui bahwa tingkat pengupahan tentang sistem pengupahan pegawai musiman di PTPN X (Pabrik Gula Camming Bone). Hal ini terlihat dari nilai $79,2 \%$ yang dalam kontinum insterprestasi skor berada di interval 61\%-80\% atau kategori baik. 2) Berdasarkan perhitungan dapat diketahui bahwa kinerja pegawai kerja musiman di PTPN X (Pabrik Gula Camming Bone) . Hal ini terlihat dari nilai $83 \%$ yang dalam kontinum insterprestasi skor berada di interval 80\%-100\% atau kategori sangat baik. 3) Berdasarkan perhitungan dapat diketahui bahwa sistem pengupahan berpengaruh terhadap kinerja pegawai kerja musiman di PTPN X (Pabrik Gula Camming Bone) sebesar 18 persen. Sisanya di pengaruh oleh faktor-faktor yang ada pada pegawai itu sendiri.

\section{DAFTAR PUSTAKA}

Abdullah,Ma'ruf. 2014. Manajemen dan Evaluasi Kinerja Karyawan. Yongyakarta: Aswaja Prasindo

As'ad, M. 1987. Psikologi Industri. Jakarta : Liberty

Hasibuan, Malayu S.P. 2002. Manajemen Sumber Daya Manusia, Edisi Revisi, Cetakan Ke Tiga Jakarta: Bumi Aksara

Kursyanto, Mangkunegara. 2007. Efaluasi Kinerja Sumber Daya Manusia. Bandung : Rafiak Aditama

Moeheriono, 2014. Pengukuran Kinerja berbasis Kompetensi. Jakarta: Grafindo Persada

Prawirosentono, Suryadi. 2008, Kebijakan Kinerja Karyawan. Yongyakarta: BPFE

Rivai, Veinthzal. 2005. Manajemen Sumber Daya Manusia Untuk Perusahaan, Jakarta: PT Raja Gravindo Persada

Sedarmayanti, 2010. Sumber Daya Manusia dan Produktivitas Kerja. Bandung : Mandar Maju 
Simamora, Henry. 2006. Manajemen Sumber Daya Manusia, Cetakan kedua. Yongyakarta : STIE YKPN

Sugiono, 2012. Metode Penelitian Administrasi. Bandung : Alfabet 
Kolaborasi : Jurnal Administrasi Publik, April 2018 Volume 4 Nomor 1 